\title{
THE INFLUENCE OF FOREIGN TOURISM FLOWS ON THE BULGARIAN INDUSTRY
}

\author{
E. Genchev* \\ Faculty of Economics, Trakia University, Stara Zagora, Bulgaria
}

\begin{abstract}
Introduction: The tourism industry is one of the fastest-growing sectors of the world economy. The tourism industry is a very important economic factor for many countries in the world, including Bulgaria.

The purpose of the present study was to examine the trends in foreign tourism flows in Bulgaria within the period $2008-2018$, as well as their influence on the structure of the tourism industry.

The tasks established by the author go in several directions:

1. Analysis of the trends in the foreign tourism flow in Bulgaria;

2. Measuring tourism's contribution to the economy, as well as its effect to the industry's structure. Material and methods:Data were obtained from Eurostat, the National Statistics Institute, and the World Council of Travel and Tourism, and analysis was by least squares multiple regression.

Results:The total effect on the tourist industry in our country is greater than the average for the EU more than $11 \%$.

Conclusion: Our research hypothesis that the tourist flow of people who are not citizens of the EU had a beneficial effect on the number of enterprises and employment rates within the "accommodation activities" sector was supported.

Keywords: Bulgaria, tourism industry, foreign tourism flows, structure of the tourism industry, tourism contribution
\end{abstract}

\section{INTRODUCTION}

According to data by the World Tourism Organisation [1], the total number of foreign tourists in 2017 had reached 1.32 billion people.

The aim of the present research was to examine the trends in the flow of foreign tourists in Bulgaria. We will consequentially review the trends in foreigners' visits to the country, their distribution into two main groups: tourists from the EU and from other countries, as well as their growth from 2008 to 2018.

For more than 10 years we have had a total increase in foreigner visits to Bulgaria by $44.9 \%$, yet in terms of visitors from $E U$ countries, it is only $26.6 \%$, while the increase for the others is $82.1 \%$ (Figure 1). This means

\footnotetext{
* Correspondence to: Assoc. Prof. Evgeni Genchev, PhD, Faculty of Economics, Trakia University, Stara Zagora, Bulgaria, , E-mail: evg_gen2000@abv.bg
}

that, throughout the reviewed period, the tourists who were not citizens of the European Union became more important to the industry than the rest. In 2018, the total number of tourists visiting our country was greater than 12 million for the first time, with the EU tourists alone being more than the population of Bulgaria.

In 2008, two out of every three tourists came from the European Union, while in 2018 this fraction was only $58.6 \%$ (Figure 2).

Interesting comparisons can be seen in Figure 3. For a period of 10 years, only in two of them, 2009 and 2015, there was an observed drop in both the total number of foreigners visiting Bulgaria and the visitors from the European Union. Something to take into consideration is that the period 2008 - 2009 was a time of economic crisis, i.e. a drop in the purchasing capacity of the EU's population could be expected, which would naturally affect the demand for tourist services considerably. 
GENCHEV E.

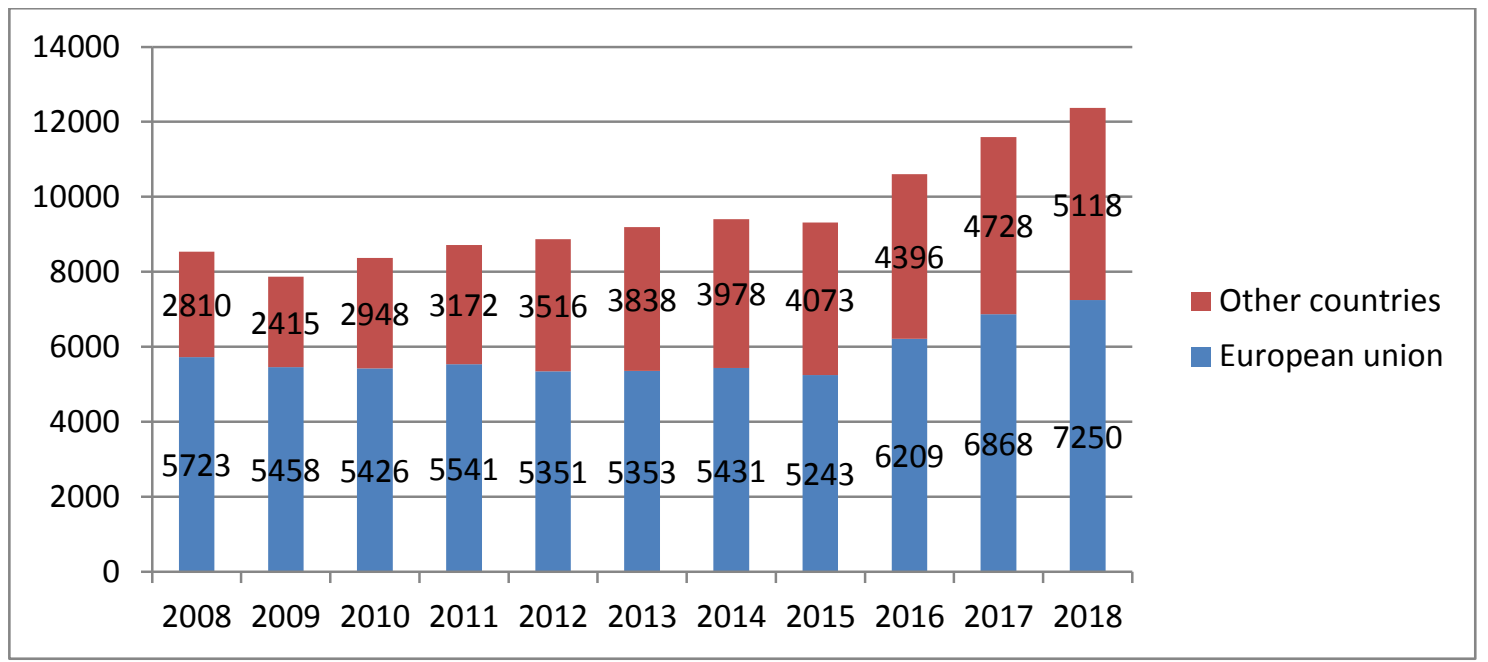

Figure 1. Arrivals of visitors from abroad to Bulgaria (in 000), Source: [2]

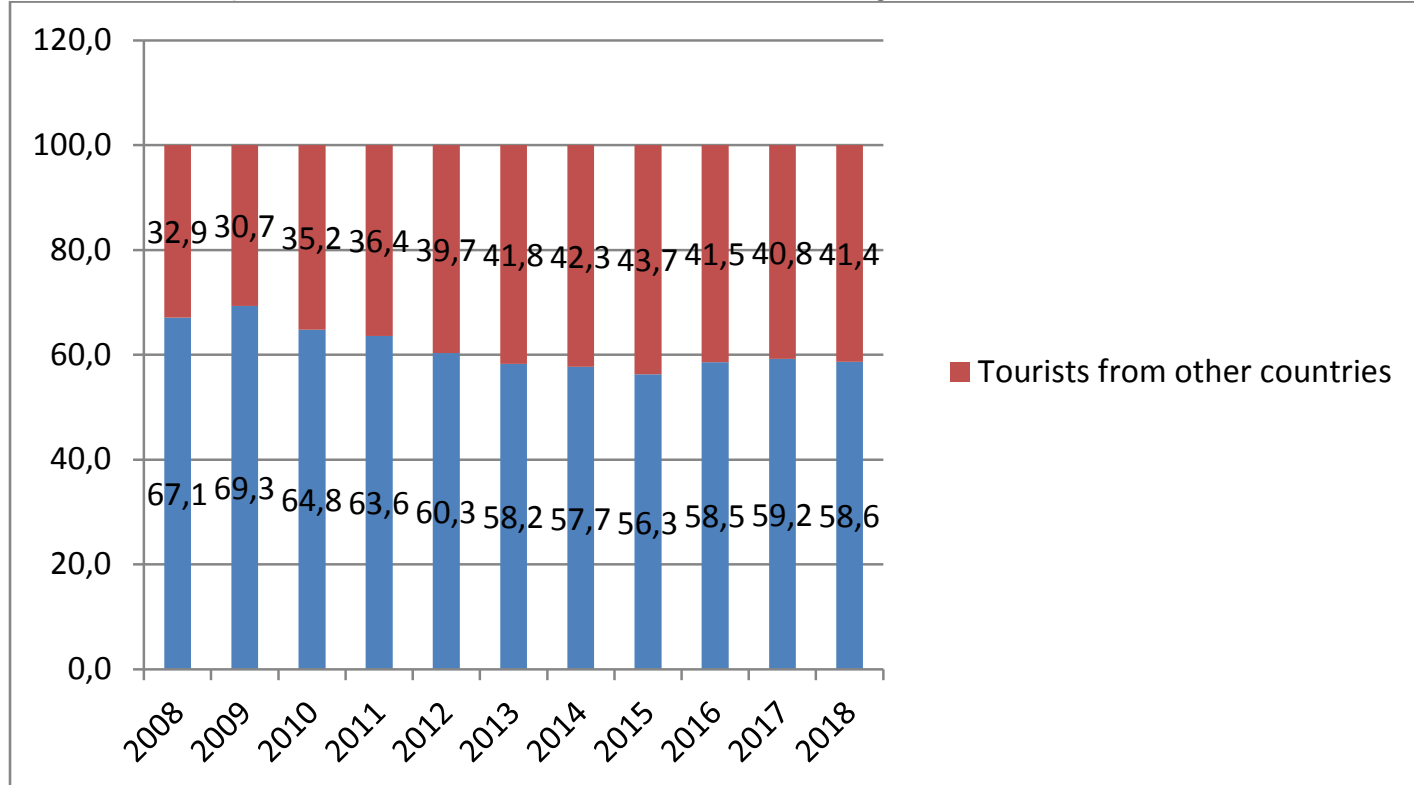

Figure 2. Share of outbound tourism in Bulgaria 2008 - 2018, own calculations

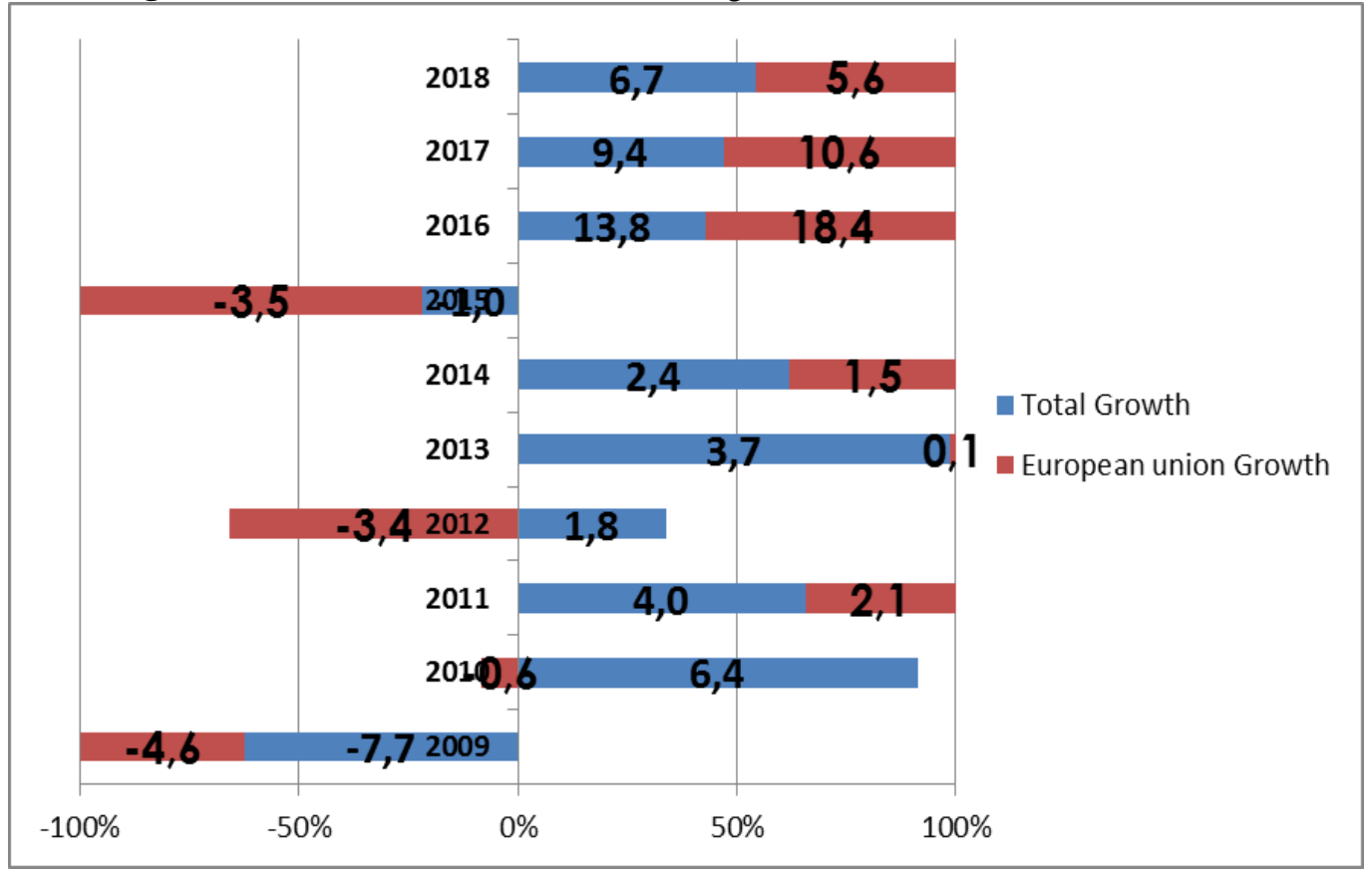

Figure 3. Increase in the number of foreigner visits to Bulgaria during the period 2009 - 2018 (on the basis of the previous year), own calculations 
Chen and Pearce [3] defined 6 types of seasons in tourism demand, depending on its seasonality. One of these types is "single-peak mountain" or a mountain-shaped shape, which is distinguished by a clearly elevated peak during the summer months. The authors positively determine Bulgaria as a country with this type of demand.

1. The contribution of the tourist industry on the economy.

The effects on the tourist industry can be measured in various directions - depending on the interconnection of the sector's activities.

- Direct contribution - the number of tourists has a strong influence on consumption throughout all sectors that offer primary services, such as hotels, restaurants, transportation, culture, sports, and recreational activities.

- Indirect contribution - investments in the tourism sector, investment expenses related to travel, as well as to buying vehicles and building new hotels, state expenses in the tourist sector, all the benefits for the subsectors related to tourists - e.g. hotel cleaning services, fuel, and catering deliveries, etc.

According to World Council of Travel and Tourism`s methodology [4], "the direct contribution of Travel and Tourism to GDP is calculated from total internal spending by 'netting out' the purchases made by the different tourism sectors. The total contribution of Travel and Tourism includes its 'wider impacts' (ie the indirect and induced impacts) on the economy".

Effect of the tourist industry on some macroindicators such as gross domestic product and unemployment.

\subsection{Effect of the tourist industry on GDP}

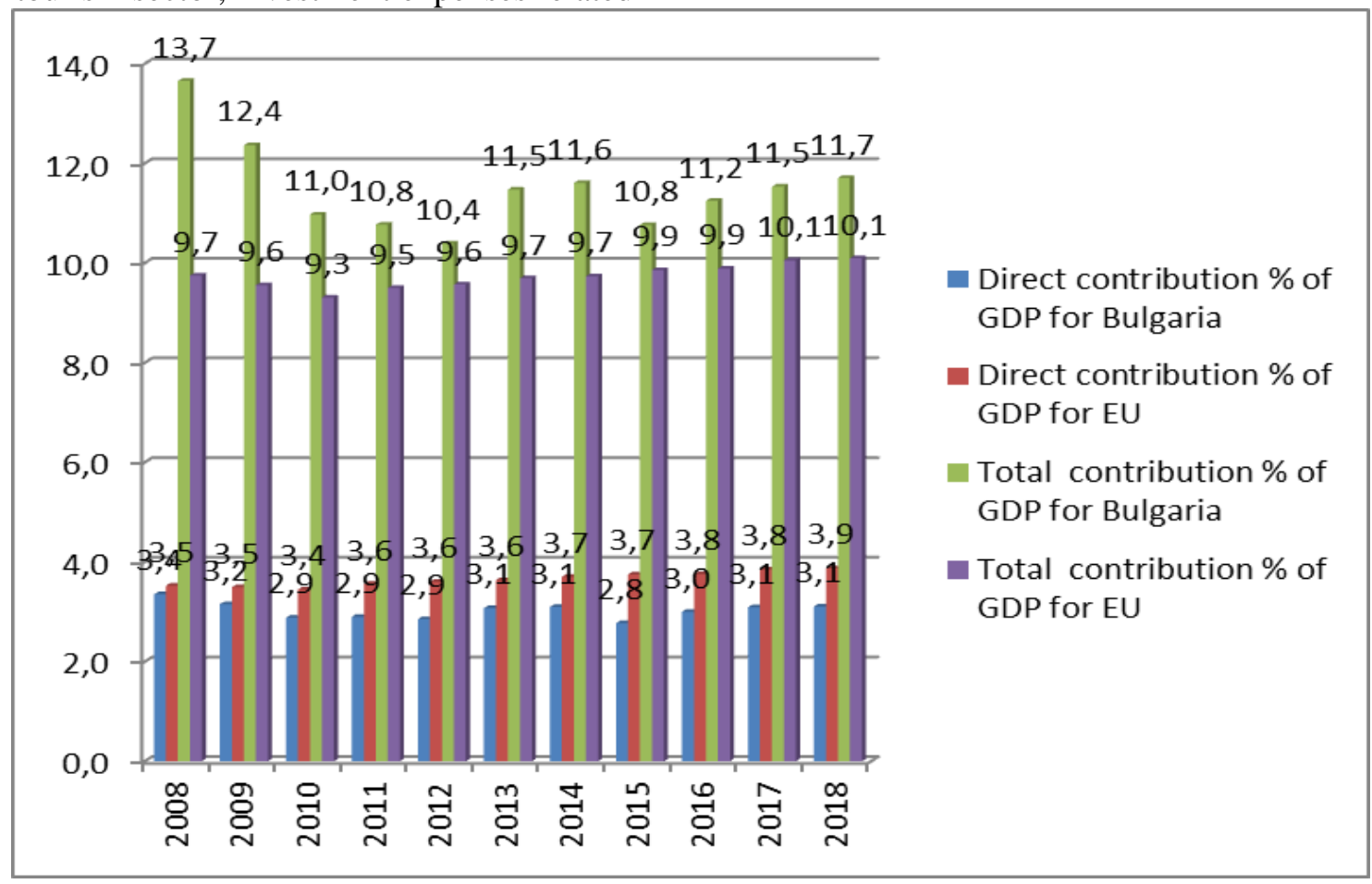

Figure 4. Tourism Contributions to GDP, Source:[5]

An interesting interpretation can be made here - the direct effects of tourism on the GDP of Bulgaria and the EU had very close values for us, it varied between $2.9 \%-3.2 \%$, while in the EU it was $3.5 \%-3.9 \%$. In average, for the studied period in Bulgaria, the direct effect was $3.03 \%$, and for the EU-3.67\%. The sectors related to the industry in the $E U$ contributed a little more than $6 \%$, and thus the overall effect reached $9.76 \%$ of the GDP on average. In Bulgaria, however, the share of the so-called sectors offering additional tourist services (cleaning, catering, entertainment, etc.) was significantly greater than $3 \%$, and so they raised the overall influence to $11.5 \%$ on average, or by more than $8 \%$. This helps us reach the conclusions that there is a greater extent of integration between firms that provide primary and secondary services in our country.

1.2 Effect of the tourist industry on unemployment

On the basis of a study on the influence of tourism on the economies of 20 countries in 
Europe in the period 2007 - 2017, the author has concluded that tourism and employment have the strongest bond in Bulgaria, with the country occupying $3^{\text {rd }}$ place out of 20 per this parameter.

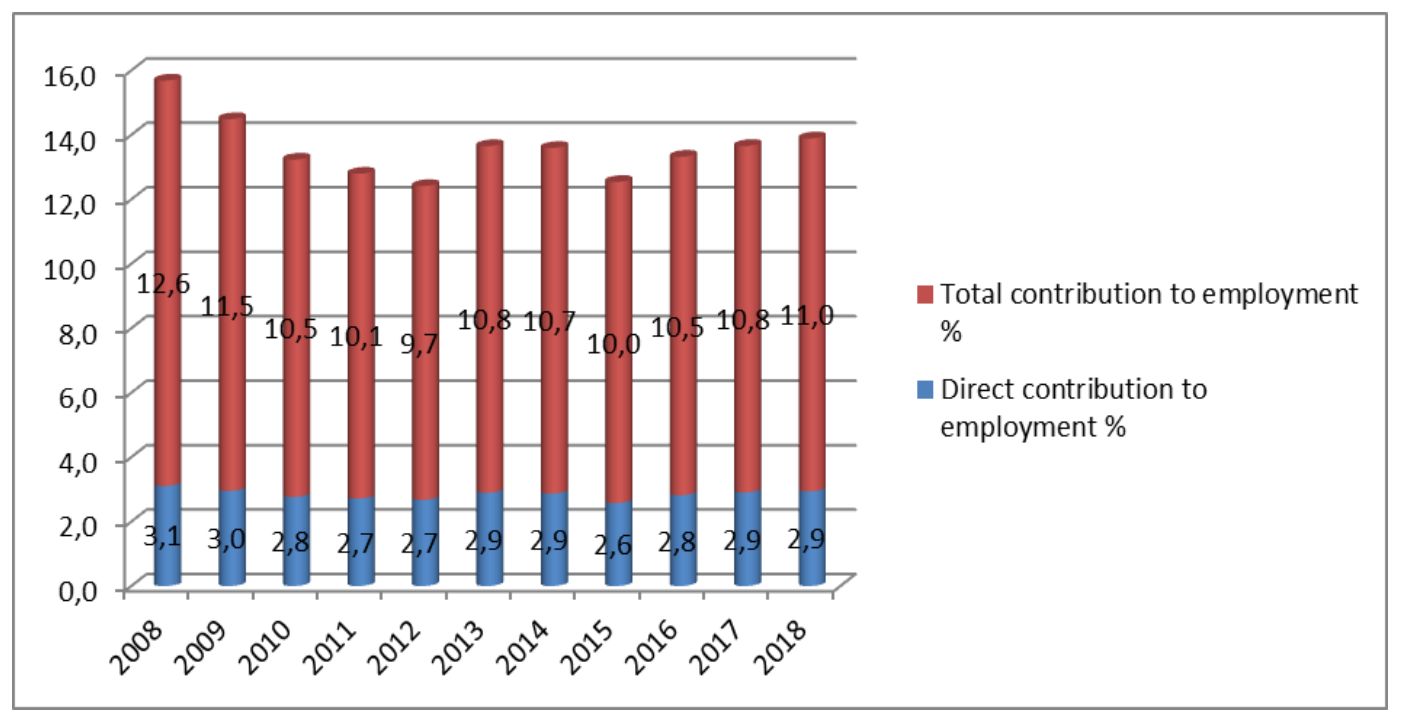

Figure 5. Direct \& Total GDP Contribution of tourism to employment in Bulgaria, Source:[5]

During the last six years, 2013 - 2018, the tourist industry (Figure 5) has contributed a total of $11 \%$ of the employees in the economy of Bulgaria. It is interesting to note that in 2008 - 2009, during the period of economic crisis, tourism had the highest direct contribution, $3.1 \%$, towards employment, with a mean value of $2.84 \%$, and a total of $12.6 \%$ in activities related to tourism.

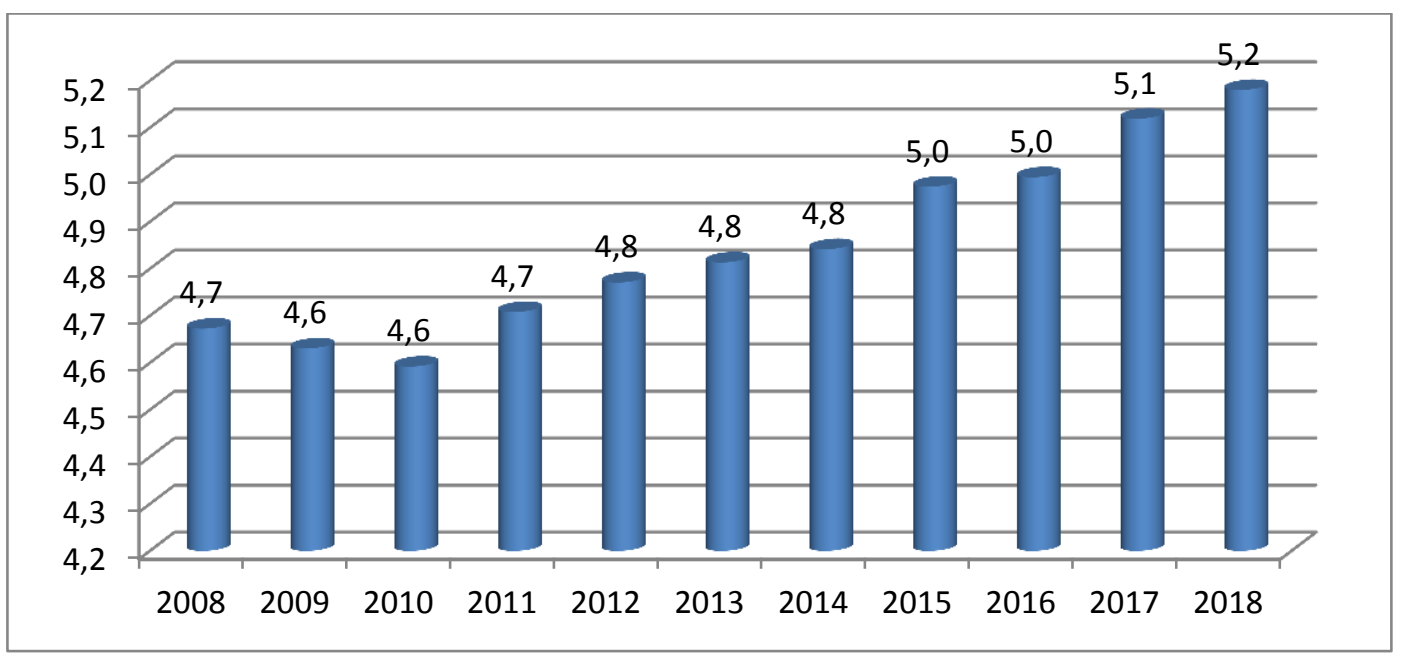

Figure 6. Direct contribution of tourism to employment in the European Union (2008-2018), Source:[5]

Even though the sector has a sizeable contribution to employment rates in Bulgaria, it is below the average levels for the European Union (Figure 6). While this percentage is around $2.9 \%$ here, in the EU it is about $5 \%$. Moreover, a gradual increase in the number of people employed in the sector has been observed in the EU since 2010, from $4.6 \%$ in
2010 up to $5.2 \%$ in 2018 , whereas our country exhibited no such trend.

\section{RESULTS AND DISCUSSION}

1.3 Influence of foreign tourists flows on the sector's structure and employment.

Before we conduct the regression analysis, we will make a short profile of the market structure in the tourism sector in Bulgaria 


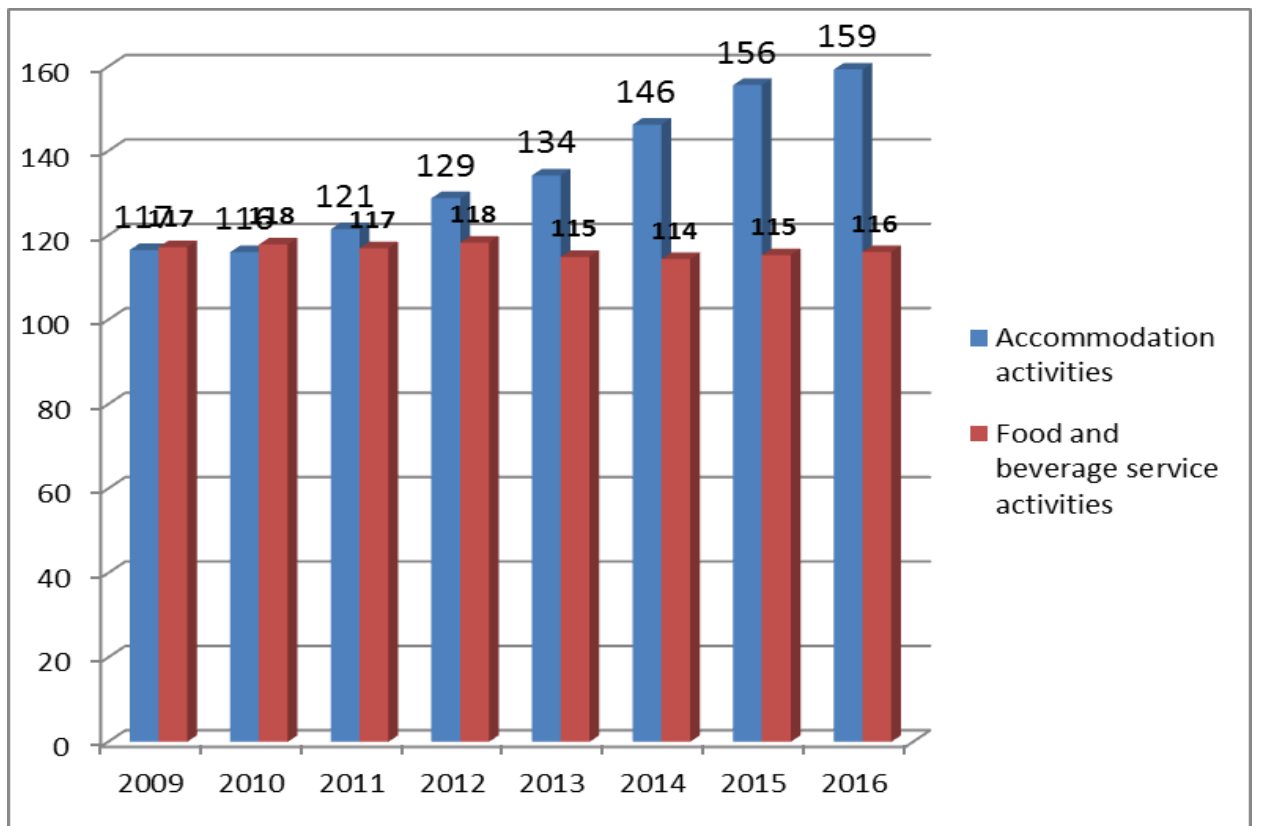

Figure 7: Increase in the number of firms in the tourism industry for the period $2009-2016$ (on the basis of 2008), Source:[6], own calculations

A constant trend of new participants entering into the "accommodation services" sector has been observed since 2011, and the total growth on the basis of 2008 is 59\% (Figure 7). The other sector, "food and beverage service" has exhibited stagnation and the growth of $17 \%$ from 2009 has "frozen" and there was no increase in the number of ventures during the following 7 years. There were close values for the growth and number of firms only in 2009 and 2010.

\section{MATERIALS AND METHODS:}

Data were obtained from Eurostat for period 2008-2016. We will use the following variables for the regression analysis:
-Dependent variables: the market structure would be examined as the total number of companies in the two primary sub-sectors and a number of employed persons in both of them.

-The independent variables would be the two main flows of foreign tourists, respectively from the European Union and from other countries. The research hypothesis would be that the flow of foreign tourists has a beneficial effect on the number of ventures and employment rates in the sector. The results of the regression analysis, conducted with the aid of the Gretl statistical program are presented below:

Table 1. Effect of the inbound tourist flows on the sector's market structure

\begin{tabular}{|c|c|c|c|c|c|}
\hline & OLS regression & Coefficient & Std. Error & t-ratio & p-value \\
\hline & $\begin{array}{c}\text { Dependent variable 1: } \\
\text { Number of enterprises in } \\
\text { accommodation services }\end{array}$ & & & & \\
\hline & Constant & 1589.13 & 1862 & 0.854 & 0.426 \\
\hline $\begin{array}{c}\text { explanatory } \\
\text { variables }\end{array}$ & EU passengers & -0.096 & 0.344 & -0.279 & 0.789 \\
\hline & Non EU passengers & 0.826 & 0.15 & 5.51 & $0.0015^{* * *}$ \\
\hline & $\begin{array}{c}\text { Dependent variable 2: } \\
\text { Number of enterprises in } \\
\text { Food and beverage service }\end{array}$ & & & & \\
\hline & Constant & 26704.6 & 7825.81 & 3.4124 & $0.0143^{* *}$ \\
\hline $\begin{array}{c}\text { explanatory } \\
\text { variables }\end{array}$ & EU passengers & -1.145 & 1.446 & -0.792 & 0.459 \\
\cline { 2 - 6 } & Non EU passengers & 0.46 & 0.63 & 0.73 & 0.493 \\
\hline
\end{tabular}

Statistically significant $* * * 1 \%, * * 5 \%$

Which of the two sub-sectors is "sensitive" towards the flow of foreign tourists?
In the "accommodation services" sector we have observed a statistically significant 
relation, but only in one of the two tourist flows - the ones not from the EU. Still, it is significant ( $\mathrm{p}$-value $\left.=0.0015^{* * *}\right)$. In the "food and beverage service" sector there was no evidence for the hypothesis that foreign tourists affected the number of companies.

Table 2. Effect of the inbound tourist flows on the number of employees in the sector

\begin{tabular}{|c|c|c|c|c|c|}
\hline & OLS regression & Coefficient & Std. Error & t-ratio & p-value \\
\hline & $\begin{array}{l}\text { Dependent variable 1: } \\
\text { Personal in accommodation } \\
\text { services }\end{array}$ & & & & \\
\hline & Constant & 34402.1 & 13008.2 & 2.645 & $0.0457^{* *}$ \\
\hline \multirow{2}{*}{$\begin{array}{c}\text { explanatory } \\
\text { variables }\end{array}$} & EU passengers & -0.671 & 2.175 & -0.308 & 0.77 \\
\hline & Non EU passengers & 2.407 & 0.519 & 4.6353 & $0.0057^{* * *}$ \\
\hline & $\begin{array}{c}\text { Dependent variable 2: } \\
\text { Personal in Food and } \\
\text { beverage service }\end{array}$ & & & & \\
\hline & Constant & 98422.5 & 29479.2 & 3.339 & $0.0156^{* *}$ \\
\hline \multirow{2}{*}{$\begin{array}{c}\text { explanatory } \\
\text { variables }\end{array}$} & EU passengers & 0.971 & 5.447 & 0.178 & 0.8644 \\
\cline { 2 - 6 } & Non EU passengers & -1.374 & 2.374 & -0.579 & 0.5838 \\
\hline
\end{tabular}

Statistically significant $* * * 1 \%, * * 5 \%$

The second regression analysis was similar to the first, which makes sense. The apparent increase in the number of companies in the "accommodation services" sector led to an increase in employment rates. The regression ratio was greater than it was in the first case, i.e. there is a stronger effect caused by foreign tourists on the labour market than on the founding of new firms. The only statistically significant variable here was the number of foreign tourists who were not from the EU. Such an effect was not observed in the other sub-sector, "food and beverages service."

Of course, the assumptions for the correct application of the ordinary least squares regression, related to "heteroscedasticity" [7] and collinearity between the independent variables were checked as well.
In all four equations we have applied White's test for heteroscedasticity - with the assumption of Null hypothesis: heteroscedasticity not present. In all cases, the critical values were higher than what was admissible, which suggests that there was no heteroscedasticity.

Does the behavior of the firms that make up the structure of the tourism industry follow the conclusions we drew earlier? If it is rational, the number of firms in the "accommodation services" sector should increase due to the constantly increasing flow of foreign tourists, especially those from countries outside the EU, by $82 \%$ (Figure 1). Let us analyze the change in the sector's structure.

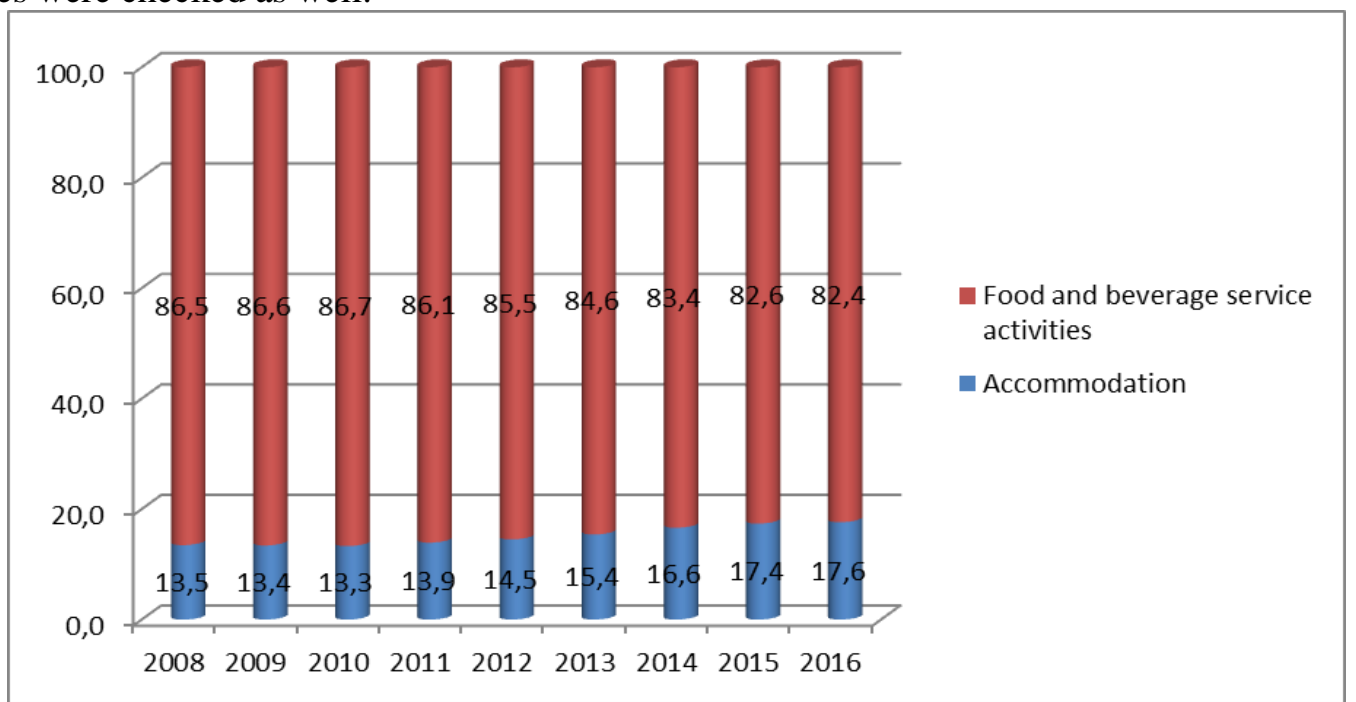

Figure 8. Relative share of enterprises in the tourism sector in the period 2008 - 2016, Source:[6], own calculations 
GENCHEV E.

Figure 8 confirms that the behavior of the firms follows the market logic: for a period of 9 years, the companies from the "accommodation services" sectors have increased their total share from $13.5 \%$ to $17.6 \%$, or $4 \%$ at the expenses of the "food service" sector. Lastly, we will examine the volume of turnovers per sub-sectors.

Table 3. Turnovers for the period 2008-2016

\begin{tabular}{|c|c|c|c|c|c|c|c|c|c|c|c|c|}
\hline Sector/TIME & $\stackrel{\infty}{\stackrel{\sim}{~}}$ & ஓ्̀ & 옴 & $\underset{\sim}{\stackrel{-}{\sim}}$ & 공 & $\stackrel{m}{\stackrel{n}{\sim}}$ & 总 & $\stackrel{n}{\stackrel{n}{\sim}}$ & $\underset{\sim}{0}$ & 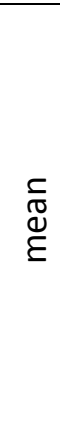 & 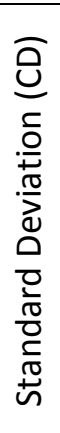 & 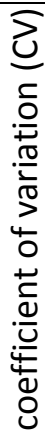 \\
\hline Total $\mathrm{N}$ of enterprises & 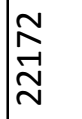 & กֶ้ & 孞 & i- & 웜 & 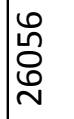 & $\stackrel{\sim}{\sim}$ & 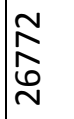 & $\underset{n}{\stackrel{N}{N}}$ & $\begin{array}{l}\infty \\
\infty \\
\infty \\
\stackrel{\sim}{\sim}\end{array}$ & $\underset{\sim}{\stackrel{G}{g}}$ & 6 \\
\hline $\begin{array}{c}\mathrm{N} \text { of } \\
\text { enterprises in accommodation } \\
\text { activities }\end{array}$ & ฉે & $\begin{array}{c}\infty \\
\infty \\
m\end{array}$ & $\underset{\substack{N \\
\mathcal{N}}}{\mathbb{N}}$ & 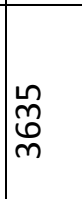 & 峁 & $\mid$\begin{tabular}{ll}
0 \\
\hdashline \\
$q$ \\
$q$
\end{tabular} & 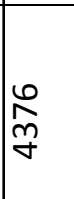 & $\begin{array}{l}\mathscr{L} \\
\stackrel{\leftrightarrow}{0} \\
\dot{\sigma}\end{array}$ & $\hat{v}$ & ने & กิ & $\stackrel{n}{\rightarrow}$ \\
\hline $\begin{array}{l}\text { Turnover per enterprise }(€ / 000) \text { in } \\
\text { accommodation activities }\end{array}$ & $\stackrel{m}{\stackrel{\sim}{\alpha}}$ & $\stackrel{n}{\sim}$ & $\underset{\sim}{\stackrel{0}{ }}$ & $\frac{0}{-1}$ & $\underset{\sim}{\stackrel{\infty}{\sim}}$ & 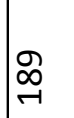 & 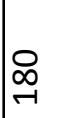 & $\underset{\sim}{\stackrel{N}{*}}$ & 吕 & $\frac{9}{7}$ & $\stackrel{\sim}{\sim}$ & $\sigma$ \\
\hline $\begin{array}{l}\mathrm{N} \text { of } \\
\text { enterprises in food and beverage } \\
\text { service activities }\end{array}$ & 各 & 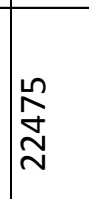 & 궁 & 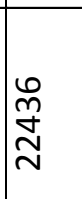 & 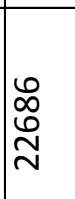 & 옹 & $\begin{array}{l}\underset{m}{\infty} \\
\stackrel{\sim}{\sim}\end{array}$ & 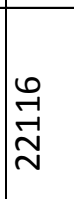 & $\stackrel{\stackrel{n}{\infty}}{\underset{N}{N}}$ & $\stackrel{-1}{\stackrel{\text { }}{\sim}}$ & $\underset{\hat{\sigma}}{\hat{\sigma}}$ & n \\
\hline Turnover in million euro & $\begin{array}{l}\infty \\
\infty \\
\infty\end{array}$ & ది & ১ু & চூ & $\underset{-}{\stackrel{-}{-}}$ & 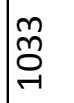 & $\stackrel{\hat{\emptyset}}{\varnothing}$ & 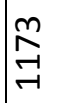 & 离 & $\underset{\sim}{\stackrel{\sim}{~}}$ & 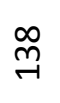 & $\underset{H}{+}$ \\
\hline $\begin{array}{l}\text { Turnover per enterprise }(€ / 000) \text { in } \\
\text { food and beverage service activities }\end{array}$ & $g$ & \& & fo & $\stackrel{m}{\forall}$ & 年 & $\hat{\gamma}$ & 守 & ñ & $\infty$ & 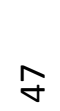 & 6 & $\stackrel{m}{\rightarrow}$ \\
\hline
\end{tabular}

Source:[6], own calculations

The industry dynamics in the accommodation services sector (Table 3) was higher because the coefficient of variation was $15 \%$ for them, as opposed to only 5\% in the food and beverage service sector. Despite its relatively higher turnover volumes, the accommodation services sector have a more constant coefficient of variation of 9\%, compared to the rest, where we observe variation by $13 \%$.

\section{CONCLUSION}

For the 10 years that were analyzed, we found a growth of $82 \%$ in the flow of tourists to Bulgaria, who are not, however, citizens of the 
EU countries, while for EU countries it was only a growth of $26.6 \%$;

The total effect on the tourist industry in our country is greater than the average for the EU - more than $11 \%$, there is an observed higher synergistic effect from the activities of the firms offering primary tourist services and the others that offer secondary services (cleaning, catering, entertainment, etc.). Furthermore, for the period from 2013 to 2018, the tourist industry has contributed about $11 \%$ of the employment in Bulgaria's labour market;

\section{REFERENCES}

\section{World Tourism Organisation-} https://www.e-unwto.org/

2. National Statistical Institutehttp://www.nsi.bg/en/content/7056/arrivalsvisitors-abroad-bulgaria-purpose-visit-andcountry-origin
3. Chen, Tingzhen, and Philip L. Pearce. "Research note: Seasonality patterns in Asian tourism." Tourism Economics 18.5 (2012): 1105-1115

4. World Council of Travel and Tourism https://www.wttc.org/-

/media/files/reports/economic-impactresearch/regions-2019/world2019.pdf

5. World Council of Travel and Tourism datahttps://tool.wttc.org/

6. Annual enterprise statistics for special aggregates of activities (NACE Rev. 2http://appsso.eurostat.ec.europa.eu/nui/sub mitViewTableAction.do

7. Rosopa, Patrick J., Meline M. Schaffer, and Amber N. Schroeder. "Managing heteroscedasticity in general linear models." Psychological Methods 18.3 (2013): 335. 